\title{
Helpers-sisters-wives: white women on Australian missions
}

\author{
Regina Ganter
}

\begin{abstract}
The contribution of women to Christian missions tends to disappear in mission historiography that is focused on the allocated roles of missionaries. Looking through the eyes of male narrators, at a range of Protestant and Catholic missions in different parts of Australia we can however decipher a pattern of the fundamental and largely unstated importance of the presence of women as knitters of family and providers of caring and compassion.
\end{abstract}

Near the dawn of the twentieth century, at the promising Bloomfield River mission in north Queensland's Daintree rainforest, well north of the tropic of Capricorn, the wife of the Lutheran Pastor Carl A. Meyer-full particulars: "Mrs Meyer”—was clearly useless: “She doesn’t do anything for the black women, she doesn't teach them anything, and prefers to do everything by herself." Incredulous, the newly arrived young Rev. Hörlein watched as this woman, "exhausts herself with work that she doesn't have to do". As if there were no black women to do the domestic work! Why didn't she just get them to do it? And the other white woman on the station “contributed nothing whatsoever to the mission”. What was wrong with these women?

In the Lutheran records, such women are barely there. As I pored for endless hours over the committee minutes in Adelaide’s Lutheran Archives, tracking the Queensland missions in a state of trance-like hyper-concentration, suddenly I hit a tripwire: "some allowance will have to be made for his widow”. Widow? Did he have a widow ... I mean, was there a wife? Then I started backtracking the last few years 
of "Correspondence \& Minutes" looking for this widow ... wife ... this woman. The visual scanning now fast-tracked into rocket speed: “What is her name? She can’t have been with him on the mission - I would have noticed!”

The patriarchal institutions propelling the century of missions were firmly fixed on the agency of white men, and many authors (including several in this volume) have despaired at the difficulty of reconstructing Indigenous people and women out of records that are so closely constructed around the white male missionaries. The Women on Missions symposium on International Women's Day 2013 was an attempt to resist one of these lacunae, and addressed a variety of roles occupied by women on missions, who were often complicit in their own historical invisibility. $^{2}$

To explore what women contributed to Christian missions, it is not enough to list their activities or involvements, because much of their contribution rests in "being there”. This becomes more evident when they are absent. Neither Aboriginal parents nor governments would surrender children into dormitory-style boarding schools unless there were women to supervise the girls, and the children transferred by governments came with a per capita subsidy, which meant that the presence of women opened a source of revenue. On Catholic missions, this role was played by the Sisters. At some missions—-like Bloomfield—we see government subsidies switched on and off in step with the presence and absence of women.

But the contribution of women that rests in 'being there' is even more intractable. The wives and children of Protestant missionaries provided the comfort of having a home, of being grounded, of “making a place”. Being at home generates stability, as much as not being at home creates longing. 
This article explores three dimensions of the presence of women. The first is the taken-for-granted domestic contribution, which comes into stark relief in the case of the Bloomfield River Lutheran mission when all the white women have left. The second is the impossibility of running a successful mission without women, shown in the case of Beagle Bay mission, a Roman Catholic mission in the Kimberley conducted by the German Pallottine order. The final dimension of women's presence rests in the centrality of kinship for social relations.

Kinship is the central mechanism for ordering relationships of respect, avoidance and support in Australian Indigenous societies. Allocating a "skin” to newcomers remains a strong custom, and researchers who visit Indigenous communities with their own families still notice that being seen as a member of a family renders a stranger more decipherable and facilitates contact. Establishing kin relations was always the primary strategy of Indigenous societies for normalising strangers, either by “adopting” them as lost kin, or by "lending wives” to forge new relationships of obligation. Most observers have considered the latter practice deplorable-whether due to eugenic or health concerns, or the presumption that it violated the free will of the women, or because unequal power relationships rendered it too easily exploitative. In many cases where Aboriginal women forged kinship links with mission staff, censured records have almost completely blanketed them from view — we might find a vague reference to a hushed-up "scandal”, or staff being eased out of missions. ${ }^{3}$

This made it all the more desirable to have married missionaries. Chief Protector Neville in Western Australia wanted to make this a matter of policy in the 1930s, when five out of twelve missions in that state were Catholic. A tradition among the Unity of Brethren (colloquially called Moravians) was to arrange 
marriages, sometimes by drawing lots, between "communal children” (Gemeinekinder) before sending out missionaries (see Edwards in this volume). The Lutherans became very adept at arranging chance encounters, either before posting missionaries (see Strehlow in this volume) or between newly arrived missionaries and suitable Lutheran girls in South Australia (see Froehlich in this volume). Sororal or affinal relations strengthened the mission fabric with personal bonds between missionary couples or with mission committees. Such missionary wives provided a safety net, knitting colleagues together into a family.

Historical sources created by men tend to give the impression that whatever the women were offering was not enough: the missionary wives at Bloomfield “contributed nothing”, and the Sisters at Beagle Bay “didn’t want to be obedient”. It takes "sustained digging"4 and reading against the grain to see what it meant to have women on missions_-or not to have them.

\section{Contributing nothing}

Emma Meyer's self-appointed judge at Bloomfield River mission in 1891, the Rev. Johann Sebastian Hörlein, was just twenty years old. At twenty, an ordained pastor and to be taken seriously, and soon to be put in charge of people at a remote mission. His life experiences had taken him from his parents’ home in Brünnau in Bavaria, to Neuendettelsau missionary college 137 kilometres away and also in Bavaria. He had recently come straight from there to Bloomfield River in North Queensland, which was then, and remains today, miles from nowhere. Hörlein had never been abroad and struggled with English. He had never experienced any climate or any culture other than Bavarian. What he knew from experience at home, he knew to be right: the only way, God's way. The way we make hay while the sun shines, lay in preserved food for winter, feed the birds through the snow so they sing in spring, and shake our purse 
at the first cuckoo - that is how the rational world properly is: dictated by nature, signed by God.

Emma Louise Kaesler had become “Mrs Meyer” in 1860 (long before Hörlein was born) when she married twenty-two-year-old Hanoverian Carl Meyer, a teacher in South Australia's Barossa Valley, on a trajectory to becoming a respected elder of the small Langmeil congregation. The couple remained childless. In 1875, they joined the Lutheran mission at Killalpaninna. Three years later, "Mrs Meyer” became "Frau Pastorin”: forty-year old Carl was ordained by Rev. Johann Flierl (see Froehlich, this volume), with whom he shouldered the Bucaltaninna/Kilallpaninna mission. Among their first fruit of converts were Johannes Pingilina and his little daughter—another Emma.

In 1886, the Meyers and Pingilina moved to far north Queensland, first to relieve Johann Flierl at Hope Valley and then to lead a new mission at Bloomfield. There, Emma Meyer set the table for five adults every day: her husband, his lay helpers Steicke (unmarried), Jesnowski (recently widowed) and Pingilina (who had left his first wife at Killalpaninna and whose second wife from Cooktown had left him). Perhaps Emma did their laundry too, washing on Mondays and ironing on Wednesdays and housecleaning on Fridays; with no shops within reach, she had Tuesdays and Thursdays for baking, preserving and growing food, and for mending and sewing. Dishwashing was done three times every day, knitting and embroidery waited until evening. She must have had help for firewood and water. She had also taken in a little girl, Timbora, who lived in the mission residence with them.

When Sebastian Hörlein arrived in the Daintree and sized up Emma Meyer in 1891, she had sixteen years of mission experience and he had none; she had run a household for thirty years and most likely he had never cooked a meal for anyone or 
starched his own clothes. He could tell that she "exhausts herself with work that she doesn’t have to do”.

The other white woman at Bloomfield mission, who also "contributed nothing”, was Anna Koch—“as big as a barrel”, according to Hörlein. ${ }^{5}$ The Kochs had arrived in 1888 with one child and now had two more, aged three and one. When Mrs Jesnowski fell ill and died in mid-1890, Anna Koch took in Jesnowski’s two children, so she had seven mouths to feed every day while minding five children. Her household might have been a little less clockwork-like than that of Mrs Meyer. She also sewed shirts for the mission, but as she didn't charge anything; this might easily have been overlooked. Her husband earned $£ 15$ per year as farm manager on the mission, so it was important to purchase as little as possible and produce their own food. There were chickens, bees, milking cows and goats to look after.

After ten years at Bloomfield mission, having found love with his wife Anna and then tragically having lost her to illness, Hörlein understood much better what such women contributed to the mission. When Anna died, there was no other woman (white or black) on the mission to take in his toddler. Three-year-old Victor was sent to Cairns to be looked after, which cost more than Hörlein was earning. Hörlein descended into depression: "I am feeling as if all life and will has departed me.”

The whole Bloomfield River mission beached itself like a tortured whale because it did not have enough women helpers. All the male staff who did not have partners, including Pingilina, were yearning for one, and a lay helper, who clearly had a relationship with at least one Aboriginal woman off the mission (never mentioned by name), caused hushed-up "scandal”. ${ }^{7}$ Without any female staff, the mission had never been in a position to take in girls, but some girls were living with the missionary families. Even before they both married, Hörlein and Rev. Johann Bogner 
had "little daughters", Timbora and Tokopati, living in the mission house. In a colourful and perhaps ill-advised published report in 1893, Hörlein yarned that both of the girls attended Sunday service, helped in the kitchen, could speak a little German, and “cheer us up”. ${ }^{8}$ (Timbora, and possibly also Tokopati, had been taken in by the Meyers, who left in 1892.) In 1899, three girls and in 1900, six girls lived in the mission residence with the Hörleins, all able to read and write (in 1901 they were sent to Yarrabah). While Anna Hörlein lay dying in the Cooktown hospital attended by her husband, a bitter dispute emerged between the two bachelors now running the mission. One of them appealed to the Chief Protector of Aborigines, Dr. Walter Roth, who visited the mission in Hörlein's absence and was scandalised to find the mission in charge of an unmarried lay-person, who now apparently either occupied the mission residence with the girls, or at least locked the girls up in the residence at night. This was the death-knell of Bloomfield River Mission: the trouble with women. ${ }^{9}$

\section{The Sisters don't want to be reasonable}

The same dynamics can be observed on Catholic missions: the contribution of female staff is dwarfed by the central male protagonists in the mission narratives, so that one must read the records against the grain to find the contribution of women.

The first Catholic mission in Australia, conducted by four Passionist priests at Stradbroke Island (1843-47), failed miserably for many reasons. They had no talent for language, including English, their relationship with Sydney Bishop Polding was strained, and their supply lines were brittle. They could not attract a resident population to conduct agricultural work, nor did they even attempt to run a school. Unlike the Lutheran Germans at Zion Hill mission in Brisbane (1838-48), who had brought their families with them, the Italian Passionists were unable to "make a 
place” out of their allocated patch of land. Three of them left with the intention of joining the commencing Benedictine mission at New Norcia, Western Australia in 1846. More than thirty years later, Catholic Father Duncan McNab, also unsuccessful in his effort to join New Norcia, attempted a mission at Durundur in southern Queensland (1877); after failing, he turned his attention to the north of Western Australia and set up a mission on the Dampier peninsula at Goodenough Bay (188486), assisted for a short while by Rev. William Treacy. McNab was also instrumental in convincing the Jesuits to set up at Daly River (1886-99). French Trappists tried to follow up with missions at Disaster Bay and Beagle Bay (1890-98) on both sides of the Dampier Peninsula. Of all these womanless Catholic efforts, only New Norcia really lasted for more than a decade. It had a female schoolmistress from at least 1865, and in 1904 the Sisters of St Joseph took over the orphanage and school. The German Pallottines took over Beagle Bay in 1900, and were in danger of closure when they were reinforced by nuns in 1907 .

The arrival of women meant that girls' dormitories could be opened and the government was prepared to allocate children who were removed by police and protectors_-along with the per capita government subsidy such children attracted. Within two years of the arrival in May 1907 of the first St John of God Sisters at Beagle Bay mission in the Kimberley, the number of children doubled and the government granted a lump sum of $£ 500$ to the mission, which had been plagued by financial worries since its inception. ${ }^{10}$

Six Sisters were in charge of running a dormitory, kitchen and a school for close to 100 children, divided into different grades, using the Department of Education curriculum. They trained the older girls in domestic work and sewing, and together with the girls produced "most of the clothing of the establishment" (there 
were about 120 persons altogether on the mission itself, plus camp residents). ${ }^{11}$ They looked after injuries, nursed patients and were expected to cook for the four Fathers and twelve Brothers.

But the mission superior, Father Bachmair, "watched his beard grow grey" from constant battles with the newly appointed Mother Superior (Sister Bernard Greene):

Difficulties everywhere, lack of funds, dissatisfaction, difficulties with the Sisters who don't want to be reasonable, especially the Mother Superior who constantly strives to find something to accuse us of. She seems to be one of those who can't let us live in peace. ${ }^{12}$

As described by Chief Protector Gale in 1910, the "convent” was attached to the girls' dormitory, which housed forty girls. One Sister slept in the dormitory, while the others shared a room next to the room for indigents and the sick, so they could all be on call during the night. The dining hall for residents had separate tables for boys and girls, and indigents gathered at one end for meals. The priests and Brothers had a separate dining hall. There is no mention of a dining area for the nuns. Of the nine Irish nuns who arrived in 1907, only six remained when Gale visited. ${ }^{13}$

While the Brothers went about producing food and income, the growing numbers of subsidised residents were primarily the concern of the Sisters. By September 1911, the number of girls had swelled to seventy-five (along with fifty boys) and between forty and fifty “old and indigent natives” were fed and clothed. ${ }^{14}$ (These people now attracted the usual government subsidy of ninepence per daymuch more than the children, at threepence per day.) In August 1912, the mission had a positive bank balance for the first time ever. ${ }^{15}$ In October 1913, the mission housed 
147 children, and twenty girls were in the sewing room. On weekends, there was usually a picnic outing to one of the surrounding wells or springs, and even if the Sisters didn't come along to organise games, they were planning and packing the picnic for whatever size group went out. ${ }^{16}$

One can only wonder about the spiritual life of these Sisters, who worked so hard and had so little privacy (see also Massam in this volume). With the whole mission chronically under-funded, the Sisters produced as much as possible on site. A cry of despair was heard from one of the Brothers:

We're supposed to make money but we had to give up the pearling boat. We're supposed to make money but we're not allowed to trade: goods purchased in bulk can only be retailed at cost price. We're supposed to make money but no Brother may absent himself from the station and miss the holy mass for more than two weeks. We're supposed to make money but by all means don’t neglect the spiritual life. ${ }^{17}$

Father Bachmair, about to hold the annual spiritual retreat (Exerzitien), for the Sisters, wrote home: “let’s hope it will bear fruit'. ${ }^{18} \mathrm{He}$ was clearly not quite happy with whatever the Sisters had to offer.

The Pallottines half-heartedly took on an outrigger mission at Lombadina, which had long been a site of Latino-Aboriginal interaction, with a strong presence of Filipino, Chilean and other migrant pearling workers. The Spanish Father Nicholas Emo, known for his good work with the coloured community, was sent to fend for himself (without subsidy) from 1910 until three Sisters from Beagle Bay arrived in 1913. By the time Father Emo died in 1915, it was felt that the Sisters were at any rate doing most of the work. ${ }^{19}$ Father Droste from Beagle Bay had some difficulties with 
the Mother Superior at Lombadina, Sister Joseph. In March 1916, she “didn’t want to sing at mass”, and in April 1916, "Sister was disobedient. Went to visit her.” Irish Sisters and German Brothers trying to work together, not bonded by the personal affection that can smooth over differences of opinion, made for a potent mix, stirred up further by the ethnic tensions introduced by World War I. According to the constable stationed at Beagle Bay to keep an eye on the Germans, Father Bachmair had forbidden all talk about the war. ${ }^{20}$ Father Droste’s tight-lipped diary on December 29, 1916 records Beagle Bay mission resident Damaso as saying that "Sisters talk and tonight mend their mouth.” A few days later, their Parochus in Broome, Father Bischofs, announced that he had been ordered to leave due to suspicions of espionage. ${ }^{21}$

In response to the tension, suspicion and surveillance that scarred mission life in these difficult times, everyone at Beagle Bay pulled together to create something extraordinary: the Sacred Heart church, now an icon of the Kimberley. Its high altar and the side altars are decorated with pearl-shell, similar to the Roter Hahn church in Arenberg (Koblenz), known to all Pallottines who had trained at nearby Ehrenbreitstein. ${ }^{22}$ Sixty-thousand bricks were turned out by the home-made kiln at Beagle Bay, children and adults collected shells at the beach to burn into lime for whitewash or use as decorations, the little "Sisters of Mary” turned flour bags into work clothes to save the good uniforms, and because the days were occupied with gathering, boiling, crushing, carting, brickmaking, sawing and building, the St John of God Sisters held lessons at night. ${ }^{23}$

Frequent supply shortages during the war are reflected in Father Doste’s diary, recording who borrowed what food from whom across the Dampier Peninsula during these years. Everyone tried to carry on business as usual, even if the raisins for the 
cake on a feast day had to be borrowed from a neighbouring station. The Feast of the Visitation of the Blessed Virgin Mary on 31 May 1916 was celebrated with a procession, and Father Droste held his sermon on the sand dune. Perhaps they found the ascent somewhat steep, because on July 14, 1916 they built a funicular (ropeway) to the top of the sandhill, and on July 31, Father Droste was back on top of the sandhill at Lombadina for the sermon, presumably less out of breath this time. The funicular was Lombadina’s answer to Beagle Bay’s Sacred Heart Church. Alas, like the "funiculí, funiculá” to Mt Vesuvius in 1880, it has long since disappeared. Since the German Parochus had been replaced by an Irish Redemptorist, October 1 was celebrated with a procession with the icon of Our Lady of Perpetual Succour.

For such processions, the Sisters made sure the children were in appropriate uniform and walking in formation. On St Martin’s Day, the children carried homemade paper lanterns and candles; on May 1, the day of St Joseph, the patron saint of workers, they pulled and pushed anything that had wheels to the blessing of the workshops and vehicles, including wheelbarrows and pull-carts loaded with dolls and (in the 1950s) teddy bears. From the letters and diaries of the Fathers, one could assume that such processions just happened by themselves; however, some of the processions, with the children all decked out in white, must have been weeks in preparation. The children's lived experience of Christian practice was to a great degree orchestrated by the Sisters working in the background.

The Sisters were not obedient enough, and did not always want to be reasonable, and sometimes the Brothers also felt that the Sisters did not impose enough discipline. Brother Rudolf Zach boasted that "in some regards I am even softer than the Sisters”, ${ }^{24}$ and when Brother Mathias Wollseifer was allocated six young women to help in the garden, he felt: 
Such a disadvantage to have to work with girls. Not that they are malicious, but you have to squeeze the work out of them. They really don’t learn to labour with the Sisters in the big house. Three or four hours a day is all you get. ${ }^{25}$

From the Brothers' records, we might note the shortcomings of the Sisters, but from the comments of mission children, we get a sense that they valued what the Sisters were offering. At Broome, the Catholic presence is most remembered through the orphanage and school run by the Irish nuns. With a predominantly coloured population, the Catholic school was the best education most Broome children could hope for. Pearl Hamaguchi pleaded with the Sisters to be allowed to stay on when she turned fourteen. ${ }^{26}$ Many former "mission girls” remember the mothering received from the Sisters. Elizabeth Fidelis Victor, who grew up at Beagle Bay mission, said "St John of God nuns were mothers to us". ${ }^{27}$ Glenyse Ward wrote the same about the German Schoenstatt Sisters at Wandering Brook mission: "the nuns were like real mums ... I suppose they were missing their families in Germany, too”. On picnic outings to the dam, “we'd be calling out to sister to look at us diving and splashing”, ${ }^{28}$ During her first Christmas off the mission, Ward teamed up with another mission girl, and

we both cried a bit, longing for the love and warmth we had experienced back in the mission ... Then all of a sudden we both got the same idea. We'd walk up the hill and see if there were any nuns in town. If there was anyone who would have compassion, it would surely have to be the nuns. $^{29}$ 
Most of Ward's positive comments about her mission upbringing at Wandering refer to the nuns, but the female staff at that mission had a particularly difficult time. The St John of God Sisters (1944-53) withdrew because they were supposed to cook for the whole staff. ${ }^{30}$ Italian Ursuline Sisters from China left within a year (1953-54), a government school teacher after just a few months because she was "no longer able to respect the authority”. ${ }^{31}$ When the first Schoenstatt Sister of Mary arrived (Sister Mary Aegidis in July 1953), she found that the school had been stripped down to the bare desks: Father Wellems had taken all the books, pads, reference and library books. $^{32}$

If someone was injured or ill, the first port of call was always a Sister. When Father Thomas Bachmair developed a mysterious pimple on his head, the first sign of his approaching death, the mission superior "took Fr. Thomas to the convent and showed Fr. Thomas' head to Sr. Visitat, who commenced to bathe it with hot water”. ${ }^{33}$ When Brother Wollseifer suffered a hernia, he called the Sister before going to the doctor. Long-term nursing on the missions also fell to the Sisters. Wollseifer, approaching death, wrote to Limburg:

Good Sister Josefa nurses me daily like a mother ...

I am practically always alone confined to my bed. A bright light is on the days when Sister comes to wash me and I become like a small child except she doesn’t put a doll in my arms. But you could hardly call it a visit. I have the highest regard for her and like to talk to her, but she only comes to perform her duties. As soon as she is finished she bundles up the laundry and is gone. She has so much to do, others are waiting, especially the six little children of lepers now in Derby ... 
There is no cook on the mission and you can't expect it of the women and girls here. That's why the Sisters cook for themselves, taking turns, even on Sundays. They also bake their own bread and send some to me, also pudding and soup. That's how I'm still alive ...

I am only surviving on the little bit of soup and pudding from the Sisters. ${ }^{34}$

With primary responsibility for health care, the Sisters were often stretched to the limits—such as when Sister Alphonse dealt with an outbreak of whooping cough that swept through the Beagle Bay dormitories. ${ }^{35}$ The Sisters in Broome had long declined to run a hospital in addition to their other duties, as Father Worms reported with incredulity:

The Sisters in Broome don’t have a hospital, and they “don’t want one because then they would have to take on midwifery. But that is against their holy rules, Amen, Hallelujah.” That's what His Most Reverend Monsignor just told me. But I cannot understand such an attitude. ${ }^{36}$

Much as the Pallottine Bishop Otto Raible was committed to offering a hospital, no thought was given to staffing a much-needed hospital with Pallottine men. ${ }^{37}$ Meanwhile, the Beagle Bay sisters looked after leprosy patients for extended periods of time. The St John of God Sisters, who had doggedly declined to be wedged between the competing aspirations of Bishop Raible and Chief Protector Neville, finally agreed to staff a public leprosarium when the Department of Public Health opened one in Derby in December 1936. The volunteer staff were Sisters Gertrude, Brigid, Matthew and Gabriel—all siblings of the Greene family. Sister Alphonsus Daly joined in 1944 and stayed for thirty-six years. It bespeaks a tremendous commitment to sacrifice. 
Meanwhile, the theological recruitment of Indigenous people at Beagle Bay mission was stepped up—again the primary responsibility of the nuns. In June 1940, the Regina Apostolorum convent for native sisters was opened to house a "pious union of native sisters” called Sisters of Mary Queen of Apostles. They started with four young novices and Sister Augustine as mother-general, and eventually admitted about thirty-eight. ${ }^{38}$ But the young women did not have their convent for long. At the end of February 1942, the Aboriginal people of Broome were evacuated to Beagle Bay mission and the Broome orphanage, itself taken over by Australian Air Force, was shifted into the Regina Apostolorum convent at Beagle Bay.

During World War II, the number of residents at the mission doubled, while its staff was halved as several German Pallottines were sent south. Amidst the overcrowding, a hookworm infestation began to spread, and five children were diagnosed with leprosy during the war years. ${ }^{39}$ To cope with the added demands, a new hospital wing and a school were built, staffed with the Sisters of St John of God and the "native sisters". Bishop Raible finally got his hospital.

Like the Protestant mission wives, Catholic nuns were pressed into the domestic realm, and their work was barely noticed and not taken very seriously by men until nursing, teaching and training eventually became professionalised.

\section{Bonds of kinship}

The function of women on missions went much beyond allocated and named roles, and it is here that they become particularly invisible — as the knitters of family, which is so fundamental to social relations. The women became substitute mothers for removed children so that even the childless women helpers on missions felt that they "had more children than most people” ${ }^{40}$ Missionary couples also informally adopted children who were brought to the mission, like the Meyers at Bloomfield. Reverend 
Georg and Pauline Reuther, with eleven children of their own, adopted a girl called Laura at Killalpanina; she moved with them to Euduna in $1906 .{ }^{41}$ At Hermannsburg, the Heinrichs raised Norman Leslie Khan, son of a camel driver, with their own children, and he moved with them to Gawler in 1932. Such transcultural families, legitimated only through the presence of women, helped to bridge the social distance between mission residents and staff.

The Catholic resurrection of kinship expressed through its terms of address not only prescribes levels of authority and equality, but helps create an identity that is based on the family of Christ. Orphanage children embraced the same strategy, turning friends into siblings:

When you look back we orphanage girls all sit back and we all laugh ... when we meet one another. And we all, we're not really related, but we all like sisters. ${ }^{42}$

Seeing each other as sisters reinforces a shared identity, and most of these children were separated from their parents and kin and reconstructed a kinship network with such terms.

The removal and separation experienced by the mission children was replicated in the experience of most of the staff, not only those leaving their homes and families to join a mission in the service of an idea. The children of missionaries were very likely to experience separation from their parents for the sake of their schooling, and the European mission societies offered boarding schools for the missionary children. Graphic descriptions of the pain of separation survive from the Heys at Mapoon and the Polands at Hopevale mission, who had lost their first-born to a shortage of food and milk. ${ }^{43}$ The "third culture kids" of missionaries, military 
personnel and other expatriates described by David Pollock and Ruth van Reken share the experience of separation from their parents, are scarred by unresolved grief and rootlessness, and often harbour deep resentment against their mothers. ${ }^{44}$ John Strehlow describes the children of Reverend Carl and Frieda Strehlow in much the same way. ${ }^{45}$ This separation arose not only from the lack of secondary schools on the missions, but also from the strong view that the primary role of missionary wives was as a wife on the mission, not as a mother to her children: being there was clearly important. $^{46}$

The generation that grew up on Christian missions used kinship terms to establish and reconfirm a personal relationship with missionaries. For his silver jubilee as a Pallottine in October 1929, Father Droste was flooded with messages addressed to "ibal” (meaning father): "we thought our eyeballs would come out from crying for you," two women wrote, a "big love and kiss for yourself” from another two who were "your housekeeper your loving aunties”. One large group signed as “your black aunties”, another three as “your aunties” (“we hope you'll be able to come back to us soon we are longing to see you back ... we must all go with nullas spears and kylies to bring you back”. Nine "aunties” wrote, "seas and distance count for naught, our first thoughts, and our kind remembrance, to our fond Ebal W Droste”. One auntie and uncle wrote, "May God bless you and spare you a long live to do some more good for your dear blacks, so now farewell dear Ebal.” The school children signed “your grateful children”, "Your fond child” or “your loving child” ${ }^{47}$ Although this flood of letters looks like a concerted action, the sentiments expressed nevertheless appear to be warm and genuine, and use kinship terms to express a bond. 
Elsewhere, too, there is evidence that mission residents found it important to view the missionaries in the context of family. Knowing someone's family establishes "familiarity". A Hermannsburg resident wrote to the Heinrichs in Arrarnta:

Mr Heinrich, my friend, I had been sick. But I'm well now. How are your 3 boys? Are they well? Did little Max forget Christina [who looked after the children]? True? Elsie and I do not forget you $!^{48}$

Theodor Abbott, addressing the Heinrichs respectively as “old man” and “young girl”, also made to sure to mention the children (in Arrarnta):

For everything, I say thank you, aiyua and kungkai! Because of all that we've shared, I cannot forget you both, or the children ... [Reporting all the people who have died.] ... Our people constantly remember you all. Those who are sick cherish deep memories of you, to the point of tears. None of us have forgotten you.

After the birth of the Heinrichs' third son (the adopted Norman Khan being the eldest):

Are the 4 boys growing up big and strong? Is kunkai also in good health? Kunkai, my good friend, how have you been of late? I hope your mother is well ... I would really like a photo of your boys. Please send pictures of them, for us to see. ${ }^{49}$

In many cases, family bonds among missionaries cemented the stability of missions and staff. The Rechner, Richter and Auricht families in Tanunda, leaders of the Lutherans in the Barossa Valley, successfully engineered many introductions, including practically all those mentioned above. Johann Flierl was introduced to 
Louise Auricht, Georg Reuther to Pauline Stolz née Rechner and Sebastian Hörlein to Anne Heinrich, and Frieda Keysser met Carl Strehlow in the living room of an ardent mission supporter in Germany just before Carl was leaving for Australia. Reverend Christian Mack impatiently wrote from Bloomfield mission to the Yorketown pastor, who on his arrival in South Australia had introduced him to a young woman:

And something else, the marriage matter hasn’t progressed at all ... when I was there I saw her for $1 / 4$ hour at Pastor Döhler's and that's all, and I haven't heard anything since then. And you write practically nothing. I don't know whether she'll take me and whether the union is God's will. If I was down south myself the matter would soon be settled. I expect an answer from you as soon as possible and if another option doesn’t turn up one way or another I'll have to come south myself. ${ }^{50}$

He came south himself, like many unmarried mission staff mentioned fleetingly in the mission committee records as "has gone south to seek a wife". The Lutheran community was keenly aware of the advantage of mission staff being married, and did its best to support the young men in finding someone suitable.

The Moravians typically arranged marriages, so sisters Mary-Ann and Matilda Barnes were married to Reverend Hey and Reverend Ward respectively, to staff Mapoon. Such sororal family bonds also strengthened the Lutheran community. Hopevale government schoolteacher Mary Allen married the mission’s Reverend Schwarz and then brought her sister Lucy from Cooktown to help teach at the mission, and Anna Poland at that mission also had the company of her sister, Mrs Beisel, for twelve years. The family genealogy of the Richter family has two Reuther sons marrying two Müller daughters, and two Roennfeldts marrying into the clan. ${ }^{51}$ 
Among Catholics in the Kimberley, five sisters from the Greene family staffed the leprosarium in Derby, and Sister Brunhilde at Beagle Bay was apparently a niece of Bishop Raible in Broome. ${ }^{52}$ Surrounded by kin and love, black as well as white people "made" their place on missions, forming an attachment to place as families.

\section{Conclusions}

The contribution of women on missions cannot be read off what they did, or did not do, because their contribution rests in "being” as much as “doing”. Missions could scarcely survive without women. Just being there was in itself important, and created the conditions of success for a mission. Governments would only consent to transfer children (and the subsidies they attracted) to a mission if there were female adults to supervise them; Catholic missions did not attempt to take in girls unless there were Sisters. Nobody seriously contested the view that a successful mission required women. Moravians kept separate service records for married women, but not the

Lutherans. But in all cases the contribution of women, premised on their "being there”, disappears in the records.

Protestant missionaries drew from their families emotional security and domestic stability, and instances where women were absent throw this into stark relief. Being wives and having children made an immense contribution to mission life, and in the eyes of an Indigenous community, being surrounded by a family humanised the missionaries. Missions were constructed around the removal of staff and residents from their kin networks, but kinship was symbolically recreated with the lexicon of family to nourish an identity of structured relatedness, a practice shared by mission residents and institutional nomenclature.

The sources on mission history direct our attention to the male protagonists on missions as if they alone could account for the story that unfolded, as if the actions of 
men were a sufficient explanation. There is a seduction in fastidiously kept records: they radiate completeness-even if we had it drilled into us as undergraduates to think of silences and absence as the tabernacle of eloquence.

\section{Notes}

${ }^{1}$ Hörlein to Rechner, 8 November 1891, Bloomfield Correspondence, Lutheran Archives Australia (LAA).

${ }^{2}$ For the self-image of women on missions, see for example Livia Loosen, “Trägerinnen deutscher Bildung, deutscher Zucht und Sitte. Alltag und Rollenbild deutscher Frauen in den Südseekolonien des Kaiserreiches”, in Frauen in den deutschen Kolonien, eds Marianne Bechhaus-Gerst and Mechthild Leutner (Berlin: Christoph Links Verlag, 2009), 40-9.

${ }^{3}$ Regina Ganter, “The Trouble with Women: Lutherans and Missions in North Queensland', in 150 Years of Germans in Queensland, ed. Andrew Bonnell (New York: Peter Lang, 2012), 81-100.

${ }^{4}$ Jonathan Richards, The Secret War: A True History of Queensland's Native Police (Brisbane: University of Queensland Press, 2008), Introduction.

${ }^{5}$ Richards, The Secret War.

${ }^{6}$ Hörlein, undated fragment, c. March 1900, Bloomfield Mission Correspondence 1886-1901 (transcriptions), LAA.

${ }^{7}$ Ganter "The Trouble with Women".

${ }^{8}$ Kirchliche Mitteilungen, 25.4 (1893): 1; and 25.6 (1893).

${ }^{9}$ Ganter, “The Trouble with Women”; see also http://missionaries.griffith.edu.au. 
${ }^{10}$ P.A. Bischofs to N.J. Moore CMB, Premier, Beagle Bay Mission, May 6, 1909 in Australien: Nachlass Kugelmannn B7d, l(1) ZAPP (Zentralarchiv der Pallottinerprovinz).

${ }^{11}$ Chief Protector C.F. Gale, December 30, 1910, Col Sec report “Aborigines and Fisheries”, microfilm 7781906 Cons 255 SROWA (State Records Office of Western Australia).

${ }^{12}$ Bachmair to Kugelmann, August 16, 1910, Australien, Nachlass Kugelmann, B7d.l (1) ZAPP.

${ }^{13}$ Chief Protector C.F. Gale, December 30, 1910, “Aborigines and Fisheries”. Sister Antonio (Bridget O’Brien), Sister Bernadine (Emily Greene), and Sister Benedict (Teresa Courtney) moved to Broome in 1908. This left Sister Patrick (Bridget O’Neill), Sister Margaret (Annabella Carmody), Sister Michael (May Power), Sister John (Ellie Walker), Sister Bridget (Katie Kavanagh) and Sister Joseph (Blanche McCaffery). Roberta Cowan, Pallottine Archives, Rossmoyne, pers. comm.

${ }^{14}$ Bachmair to Kugelmann, September 19, 1911, Australien, Nachlass Kugelmann, B7d.l (1) ZAPP.

${ }^{15}$ Bachmair at Beagle Bay to Kugelmann in Masio, August 20, 1912, Australien, Nachlass Kugelmann, B7d.l (1) ZAPP.

${ }^{16}$ Bachmair Report for Beagle Bay, October 2, 1913, 1913 Chief Protector’s Report for Beagle Bay, microfilm 7781906 Cons 255 SROWA.

${ }^{17}$ Kasparek to Kugelmann Ostern 1913 Australien, Nachlass Kugelmann, B7d.l (1) ZAPP.

${ }^{18}$ Bachmair to Kugelmann, August 16, 1910, Australien, Nachlass Kugelmann, B7d.l (1) ZAPP. 
${ }^{19}$ According to Nailon, the Sisters at Lombadina were Superior Mother Joseph, Patrick and Therese, but Droste refers to Sisters Joseph, Patrick and John (Blanche McAffery, Bridget O’Neill and Ellie Walker, all previously at Beagle Bay). Sister Brigida Nailon CSB, Nothing is Wasted in the Household of God-Vincent Pallotti's Vision in Australia 1901-2001 (Richmond: Spectrum, 2001): 42-4. From 1914 to 1916, Droste also mentions Sister Bernadine (Emily Greene), “Sister M.” (possibly Sister Mathew Greene), Mother Benedict (Teresa Courtney), Sister 7th Dolor, Sister 6th Dolor, Sister Carrying of the Cross, Sister Flight, Sister Laetare (meaning Joy), Sister Sacred Heart, Sister Nativity, Sister Xavier (perhaps Mother Francis Xavier Sullivan) and Sister Agatha, but it is not clear which of these women were normally at Broome, Beagle Bay or Lombadina, or visiting. In April 1915, he refers to five Sisters at Beagle Bay. Droste diary, ZAPP.

${ }^{20}$ Constable F.H. Watson at Beagle Bay to Intelligence Section Major Corbett, June 9, 1917, PP14/1/0 - 4/4/22 (B795928) C, NAA.

${ }^{21}$ Droste diary, January 1, 1917 in Wilhelm Droste [P] P 1 Nr 17 ZAPP. This military order, incidentally, had been issued in October and did not result from the Sisters’ comments.

${ }^{22}$ File note in Droste, Wilhelm [P] P 1 Nr 17 ZAPP.

${ }^{23}$ Droste’s diary in 1913 mentions Sister M. Simeon, Sister Alacaque [Kenny], Sister Mathew [Greene], Sister Simeon and Sister Mary of the Cross.

${ }^{24}$ Zach at Beagle Bay to Kugelmann, August 15, 1912, in Brother Rudolf Zach (1870-1928) P.1-24 ZAPP.

${ }^{25}$ Wollseifer at Beagle Bay to Kugelmann in Limburg, 2. Advent 1933 in Australien Nachlass Kugelmann B7 d.l. (1) ZAPP. 
${ }^{26}$ Author’s interview with Pearl Hamaguchi, Broome, 1995.

${ }^{27}$ Elizabeth Fidelis Victor, in Sister Brigida Nailon and Father Francis Huegel, This is Your Place: Beagle Bay Mission (Broome: Pallottine Centre, 2001), 22-3.

${ }^{28}$ Glenyse Ward, Wandering Girl (Broome: Magabala Books, 1988), 7.

${ }^{29}$ Ward, Wandering Girl, 148.

${ }^{30}$ Sister Gertrude 1952, cited in Edmund John Gallagher "Wandering Mission as Part of the Pallottine Mission Effort in Assimilating the Australian Aboriginal' (Thesis for Teacher’s Higher Certificate, 1971).

${ }^{31}$ Wandering mission records 1952, cited in Gallagher, "Wandering Mission”, 49.

${ }^{32}$ Gallagher, “Wandering Mission”, 50.

${ }^{33}$ Droste diary, August 23, 1918, in Wilhelm Droste [P] P 1 Nr 17 ZAPP.

${ }^{34}$ Wollseifer, February 6, 1952 in Wollseifer, P1-25, ZAPP.

${ }^{35}$ Beagle Bay Mission, Broome, Western Australia, B77 PT1 A885, NAA.

${ }^{36}$ P Ernst Worms SAC to P Nekes, Broome 12 May 1933 in Nekes, Australien B7d,l(2) ZAPP.

${ }^{37}$ Nailon, Nothing is Wasted, 80.

${ }^{38}$ Nailon, Nothing is Wasted, 139; Margaret Zucker, From Patrons to Partners: A History of the Catholic Church in the Kimberley (Broome, University of Notre Dame Press, 1994), 115, 98.

${ }^{39}$ Zucker, From Patrons to Partners, 111-12.

${ }^{40}$ Laura Rademaker, ““I Had More Children Than Most People’: Single Women’s

Missionary Maternalism in Arnhem Land, 1908-1945', Lilith 17 (2012): 7-21. 
${ }^{41}$ Pauline Reuther, letter at Gumvale, October 8, 1929, in Judy Gale Rechner, G.J. Rechner and his Descendants: Rechner, Fischer/Fisher, Stolz and Reuther Journeys (Adelaide: Rechner Researchers, 2008), 235.

${ }^{42}$ Ollie Smith, in Christine Choo, Mission Girls (Perth: University of Western Australia Press, 2001), 140.

${ }^{43}$ Biographies of Poland and Hey at Regina Ganter, German Missionaries in Australia website, accessed 20 February 2014, http://missionaries.griffith.edu.au.

${ }^{44}$ David Pollock and Ruth van Reken, Third Culture Kids: Growing Up Among Worlds (London: Nicholas Brealey 2001).

${ }^{45}$ John Strehlow, The Tale of Frieda Keysser, Volume I: 1875-1910 (London: Wild Cat Press, 2011).

${ }^{46}$ See, for example, Susanne Froehlich's biography of Louise Flierl at http://missionaries.griffith.edu.au.

${ }^{47}$ In Droste, Wilhelm [P] P 1 Nr 17 ZAPP.

${ }^{48}$ October 1933, unknown to Hermann Heinrich, in Ntaria School “Dear Mr Heinrich—Ntaria Letters 1933-35’, Hermannsburg 2002, 23. The letter reads: “Mr Heinrich, tjina nuka, yinga minta naka. Yinga lyaarta itaarrknga wutha nama. Wurra 3 nthaakinha paka nama? Marra paka? Max kurrka kala kngwerraka. Kristina-ka rrankarra nthurrpa kala kngwerraka. Elsie ilirna itja rrankarraka kngwerrama.” ${ }^{49}$ Ntaria School, “Dear Mr Heinrich”, 23ff.

${ }^{50}$ Mack to Rechner, 16 July 1899, Bloomfield correspondence, LAA.

${ }^{51}$ Rechner, G.J. Rechner and His Descendants.

${ }^{52}$ Mercia Angus in Sister Brigida Nailon and Father Francis Huegel, This is Your Place_Beagle Bay Mission (Broome: Pallottine Centre, 1990), 141. 